\title{
Can High-Tech Companies Enhance Employee Task Performance through Organizational Commitment?
}

\author{
Li-Yu Tseng (Corresponding author) \\ Graduate School of Business Administration, Fu Jen Catholic University \\ 8F., No.278, Wenlin N. Rd., Beitou Dist., Taipei City 112, Taiwan \\ Tel: +886-02-2827-9316_E-mail: juliatseng8@yahoo.com.tw \\ Tian-Shyug Lee \\ Department of Business Administration, Fu Jen Catholic University \\ No.510, Jhongiheng Rd., Sinjhuang City, Taipei County 24205, Taiwan \\ E-mail: badm1004@mail.fju.edu.tw
}

Received: February 23, $2011 \quad$ Accepted: April 27, 2011 doi:10.5430/ijba.v2n2p94

\begin{abstract}
Prior studies about task performance within the high-tech industry have focused mainly on the relationship among working stress, working characteristics, employee motivation, and the compensation system. This study, however, examines whether employee personality, organizational culture, and different leadership styles have an impact on organizational commitment and hence increase the employee's task performance. To study this issue, 304 employees from high-tech public companies in Taiwan were selected as illustrative example, and LISREL software was used as the analytic tool. The research findings indicate that high-tech companies whose employees exhibit personality characteristics such as competition and high ambition (typically "Type A") have a positive effect on organizational commitment. Second, high-tech companies exhibiting an innovative and supportive culture also have significant impact on organizational commitment. Third, employees with more value commitment and effort commitment show increased task performance. In addition, organizational commitment acted as an intermediary role between employee personality characteristics, organizational culture, and task performance; that is, employee personality characteristics and organizational culture indirectly influenced task performance through organizational commitment.
\end{abstract}

Keywords: Employee personality characteristics, Organizational culture, Leadership style, Organizational commitment, Task performance

\section{Introduction}

In the world's constantly changing economic environment, global industries must cope not only with the impact of globalization, but also the growth of emerging countries such as BRICs and the Next Eleven and various uncertainties. The government, therefore, should promote a policy of developing ten high-technology industries including consumable electronics, communications, information, semiconductors, precision instruments and automation, spaceflight, advanced materials, specialty chemicals and pharmacy, and medical care and contamination control. The focus of such development should be in addition to enhancing and upgrading traditional industries, in order to increase the output value of high-tech industries in manufacturing from $27.4 \%$ to $42.3 \%$ (Ministry of Economic Affairs, R.O.C.). Among high-tech industries, the entire output value of the integrated circuits (IC) industry in Taiwan (including designing, manufacturing, packaging, and testing) achieved NTD 478.1 billion in the third quarter of 2010, with an increase of $29.6 \%$ over the same period last year. In the global communications industry, a range of Taiwan products hold more than $80 \%$ of OEM orders worldwide, not to mention top market shares (http://www.eettaiwan.com).

In our current knowledge economy, an enterprise cannot gain high profits by merely using entity assets and relying on product sales; therefore, enterprises are gradually changing their focus from deployment strategies to the importance of people (Dearlove, 2005). Personality characteristics reflect an employee's unique personal characteristics, which will have different dynamic characteristics due to different environments. Employees in high-technology industries are under high pressure every day. It is more necessary, therefore, to examine their personality characteristics in order to fit them with suitable jobs, both for productivity and employee satisfaction. Personality, therefore, holds some explanatory power 
and capacity to forecast how personal behaviors are expressed. Achieving personality fit with a position can enable employees to work with high proficiency and promote work performance efficiently, thus creating positive business performance.

With increasingly severe international competitive conditions, the speed at which the economy changes has become the business symbol of this century (Sprenger, 2004). Teamwork has become a necessity for the success of an enterprise organization. Trust is the catalyst of teamwork. In either interactions between directors and subordinates or among colleagues, trust can create valuable synergy. In particular, leaders who intend to understand others' beliefs and gain respect, loyalty, and cooperation must motivate each individual to pursue accomplishments toward the company's vision. Leaders do this by setting directions, encouraging employees to participate and communicate, and by stimulating morale. To promote quality performance, an enterprise must adopt effective leadership patterns with trust between employees and directors. This will encourage employees to achieve their work performance actively and to help the organization achieve its expected goals.

The creations, viewpoints, values, and hypotheses shared among members of an enterprise and consistent perceptions within an organization have common characteristics. These characteristics describe and distinguish the differences among organizations and bring together personal, group, and organizational system variables, forming an organizational culture that differs from other organizations (Dyer, 1985; Robbins, 1998). Organizational culture can also be used to represent shared values, beliefs, and practices among organization members (Denison, 1996; Greenberg \& Baron, 2000). Externally, an organization's culture presents a corporate image, becoming a powerful tool that the outside world uses to identify different organizations (Kast \& Rosenzweig, 1985; Robbins, 1998). Internally, culture can regulate or restrict members' mutual cooperative behavioral habits and motivate them to comply with organizational goals (DeLong \& Fahey, 2000). Organizational culture is not only a system of distributing economic power (Dobson, 1990), but also a strong mediating force that causes members to unify, cooperate, and strive for business goals together (Gordon \& Ditomaso, 1992). This enables employees to devote themselves proactively to the enterprise (Gardner, 1985).

Organizational commitment is the degree to which employees identify with the organization and its goals and hope to remain a member of the organization (Mayer \& David, 1998). It is also a status that shows the extent to which organization members are willing to make efforts and have the capacity to work for and be loyalty to the organization or the goal pursued. In return, the employee generally achieves work satisfaction (Hodge et al., 1996). If an enterprise seeks to make employees identify with the organization and its goals, the best way is to launch a trust mechanism (Sprenger, 2005). Leaders must actively take the lead in this initiative, because the higher trust element will help employees feel control measures that help provide information and support, encouraging them to also offer trust. A series of trust feedback, therefore, will be initiated (Sprenger, 2005); employees will have appetence to maintain their organization member status, believing deeply and accepting organizational goals and values and be willing to become involved in great efforts for the organization (Porter et al., 1974). As such, employees will make more effort to perform tasks on their own initiative.

Task performance refers to the value of an employee's task contribution and the quality or quantity of a task. In other words, it refers to an employee's productivity; a higher level of productivity will indicate higher overall operational performance of the organization. Schermerhorn (1989) considered that good task performance is basic because an organization's human resources must have the capacity to fulfill the task, be willing to make necessary efforts, and have sufficient support. Among the above qualities, capacity is the most important. Campbell (1990) believed that task performance is the behavior that an individual performs as an organization member in order to accomplish the demands of a role that are expected, stipulated, or formalized by the organization. That is, behavioral performance indicates that an employee has the capacity to complete the task within a given period. It also means the benefit plan that a subordinate or a group achieves the goal to make it contribute to organizational goal.

In our rapid and competitive era, most enterprises, in pursuing private interests, will take strategies, resource allocation, and coordinated control into consideration to enhance their business performance. In addition to using the accomplishment of strategic goals to evaluate business performance, neglecting the efficient completion of tasks is the most fundamental source of performance. Moreover, previous studies on the high-tech industry have mainly focused on work pressure (Yu, Lin \& Hsu, 2009; McCalister, Dolbier, Webster, Mallon \& Steinhardt, 2006); the impact of salary on task performance (Chien, Lawler \& Uen, 2010); promoting technical performance (Hagedoorn \& Duysters, 2002); and the ability to innovate products (Menguc \& Auh, 2010). Few studies have explored high-technology performance based on the traits of the employees themselves. This study, therefore, intends to discover the causes that affect the task performance of high-technology industry employees from perspectives such as employee personality characteristics, organizational culture, leadership style, and organizational commitment. Using a Linear Structural Relation (LISREL) 
model combining factor analysis and path analysis, which allows simultaneous processing of the causality among multiple groups of independent variables and dependent variables(Hayduk, 1987), this study differs from traditional multivariate analysis. It uses LISREL to verify the research hypotheses of variables including employee personality characteristics, organizational culture, leadership, organizational commitment, and task performance. The study's aim is to provide enterprises with suggestions for managing strategy based on objective empirical results.

\section{Literature Review and Research Hypotheses}

\subsection{Evaluating organizational commitment}

Organizational commitment refers to an individual's performance and loyalty to an organization. The more loyalty an employee has to an organization, the more willing he or she wants to exhibit high organizational commitment (Angle \& Perry, 1981). Organizational commitment, therefore, is a kind of attitude response at work (Koch \& Steers, 1978). It also includes a sense of belonging to the organization, a connection and citizenship behaviors, which promote operational efficiency. Such qualities also effect the organization through the employee's contribution of resources, innovation, and adaptation to the environment (Williams \& Anderson, 1991). Organizational commitment is the degree to which employees believe and accept the organization's goals and values, input highly strenuous value commitment and effort commitment to the organization, and hope to become or remain a member of that organization (Robbins, 1998). In terms of the organization, organizational commitment can predict the effective prescription of employee and organizational performance (Steers, 1977). Simultaneously, management also expects to seek methods of retaining employees and promoting operational performance through knowledge of organizational commitment.

Porter et al. (1974) considered that organizational commitment consists of the following: (1) value commitment, meaning employees believe and accept the organizational goals and values; effort commitment, which involves employees expending great effort; and retainment commitment, meaning that employees are willing to maintain their membership with the organization. Stevens, Beyer, and Trice (1978) believe that the commitment an employee is willing to make to retain membership in the organization and expend more effort on the organization's behalf belongs to normative commitment. This means the employee believes he "should" make such efforts to comply with the "norms" of the organization. Further, an organization member is able to evaluate the exchange commitment; that is, the gap between his contribution to organization and the remuneration gained. Allen and Meyer (1991) proposed that employee commitment to the organization includes (1) emotional commitment, meaning an organization member is willing to make with the hopes of staying with the organization to offer service; (2) durative commitment, meaning the employee considers external employment opportunities and the cost of leaving the company; and (3) normative commitment, which motivates the employee to maintain loyalty to the organization. By summarizing studies of other scholars and considering the peculiarity the high-tech industry, companies usually adopt a responsibility system, which often includes bonuses or dividends. This study combines opinions of scholars such as Porter et al. (1974), Stevens, Beyer \& Trice (1978), Schechter (1985), and Allen and Meyer (1991) among others, dividing organizational commitment into normative commitment and exchange commitment.

\subsection{Evaluating leadership style}

Former studies have emphasized that leadership is inborn in order to explore the relevance between leadership effectiveness and inter-leader behaviors and to stress that effective leadership depends on the influence of circumstance. The current study, however, attaches importance to leaders with prospects and the relevance of their leadership behavior models. Scholars such as Burns (1978), Bass (1985), Bass and Avolio (1997) have observed leadership behaviors from different viewpoints. They divide leadership behavior into "transactional leadership" and "transformational leadership." Transactional leadership is a process of reciprocal interchange, meaning leaders use tangible and intangible conditions to transact with subordinates to gain leadership. Transformational leadership uses a completely different viewpoint or realization to deal with leadership issues, meaning the leader offers personal concern and mental inspiration using his or her personality characteristics. Transformational leaders regard every employee as an individual and offer appropriate suggestions and experience. This helps the employee develop their self-actualization needs, enabling employees to see that higher level objectives are achievable (Kuo, Ho, Wu \& Lin, 2010). The high-tech industry, however, is characterized by rapid change. If a leader merely relies on personal charm or performs military management, he or she might not be able to influence employees. This study therefore takes the opinions of Burns (1978), Bass (1985), and Bass and Avolio (1997) to divide leadership style into transactional leadership and transformational leadership.

Facing competitive and an ever-changing market, development and survival can fall entirely on leaders, whose words and deeds are interlinked with the company's prospects. If a leader can read the expectations of those being lead, it is easier to achieve organizational goals between the leader and employee, allowing the leader to stand apart and not interfere with the employee's work (Burns, 1978). Taking a wide view, to gain others' beliefs, respect, loyalty, and 
cooperation, a global enterprise leader sets directions for the future of the enterprise, stimulates morale through employee participation and communication, gathers employees' feedback, and helps each individual work toward accomplishing the company's vision actively and with initiative. Leaders inspirit employees to increase their level of effort and inspire employees' to be conscious of their personal behaviors rather than connecting such behaviors to the exchange behavior of the rewards and punishments system. Using transformational leadership, therefore, can cause an organization's members to feel trust, respect, and loyalty. It can also promote organization members' commitment to organizational goals, bring about intentions and motivation to make effort on behalf of the organization over personal expectations. It does this in part by changing members' values and beliefs, developing their potential, and giving them confidence. Leaders can also use transactional leadership to manage subordinates' morale and help them achieve their goals with rewards or discipline by identifying work roles, expected performance, and task performance (Gustafson, 2001).

\subsection{Personality characteristics and organizational commitment}

Personality is a unique characteristic among people and is something through which previous behaviors can forecast future behavioral patterns (McCrae \& Costa, 1986). Because a person's response to circumstances includes both structural and dynamic performance (Pervin \& John, 1997), it is a permanent characteristic and has a tendency to determine an individual's commonality and differences with others (David, 1989). Personality characteristics also refers to personal psychological and physiological phenomenon; it is a syntheses used to differentiate individual psychological characteristics (Robbins, 1998). Personality will express unique psychological characteristics according to different times and circumstances and will determine a person's behavior and thought processes in order to adapt to varying circumstances. Rotter (1954) advanced the control theory on the basis of the social learning school, thinking that cognition variables must be considered to forecast human behavior in special circumstances. Rotter thus divides personality into two types: (1) internals, where an employee believes he can control his own fate and any result is caused by personal capacity and attributes and (2) externals, where an employee thinks all control and results of life come from external powers. Maslow (1973) divided personality into five levels on the basis of motivation: physiological needs, security needs, love and need for belonging, esteem, and self-actualization. Friedman and Rosenman (1974) advanced type A/B personalities. These scholars believed that persons with type A personality characteristics have a strong motivation to overcome barriers, are competitive, enjoy power and recognition, anger easily, take actions quickly, are achievement-oriented, make multiple attempts, are aggressive, do not like wasting time, and are energetic and have effective way of acting. On the contrary, persons with type B personality characteristics are more relaxed and not irritable. They sometimes work hard, but are not as impulsive and strong as type A. Nor do they like competition as much as do type A personalities, do not anger easily, and may be slow to take actions. Costa and McCare (1986) put forward five personality factors including neuroticism, extraversion, openness, agreeableness, and conscientiousness. Considering the severe competition in the high-tech industry, internal employees should have characteristics such as the capacity to overcome barriers, energy, and consistency in accepting challenges. This study therefore uses the type A/B personality characteristics of Friedman and Rosenman (1974) and internal/external control personality characteristics of Rotter (1954) as independent variables.

Personality characteristics will affect the individual's tendency to identify with the organization; for example, personality will affect an individual's achievement motivation, concept of values, gender roles, overt need, among other things (Hellriegel \& Richards, 1998). The more management pays special attention to intrinsic change, innovation, and the psychology of its organization's members (Deming, 1994), the more the management will learn about the employees' psychological needs. As a result, the more the management will target employees' needs and preferences to promote employees' commitment to the enterprise. This will help the organization easily face the external pressure of competition (Chang \& Lee, 2006; Senik \& Verdier, 2008). Different personality characteristics, therefore, have significant approaches to organizational commitment. Based on the above studies, this study aims to prove that personality characteristics are significantly correlated with organizational commitment and further explore whether different employee personality characteristics make a significant difference to organizational commitment. The following hypotheses are thus proposed:

Hypothesis 1: Different employee personality characteristics make a significant difference to the intention of organizational commitment

Hypothesis 1-1: The more the employee's personality characteristics belong to internal control, the higher the employees' intention to organizational commitment.

Hypothesis 1-2: The more the employee's personality characteristics belong to type A, the higher the employee's intention to organizational commitment. 


\subsection{Organizational culture and organizational commitment}

Enterprises regard organizational culture as an operating philosophy and the intrinsic variable of an organization, even the key factor for success when enterprises are implementing strategies. Thus organizational culture is a meaning system that organization members own together; a meaning system that differentiates one organization from others (Robbins, 1998). It is a set of values, beliefs, and a behavioral model that can establish the core of an organization (Dension, 1990). Based on the orientation of organization development, Ansoff (1988) uses a strategic point of view to divide organizational culture into four types: stable, passive, explorative, and creative. Considering that an organization has different flexibilities and internal/external orientations, Wallach (1993) put forward bureaucratic, innovative, and supportive organizational culture types. In 1985, Cameron pointed out that effective culture should be added. Considering that the high-tech industry is characterized by intensive technology, capital, technical manpower, high risk, and short product life cycles, high-tech enterprises should pay attention to employees' capacities to face challenges and innovation. Meanwhile, high-tech enterprises should offer a high level of support, equality, and encouragement; focus on human-based management; and create an interpersonal relationship-oriented work environment with supportive cultural characteristics that promotes sales achievement and service. This study therefore adopts the innovative and supportive organizational culture as proposed by Wallach (1983).

Organizational commitment is a characteristic of integrity that creates normative pressure through internalization, which causes employees' patterns of behavior to comply with the organization's goals and interests (Wiener, 1982). When an organization features a cohesive consensus culture, the entire organizational commitment correlativity will be higher. When an organization has a consensus culture, that is shared widely among all the organization's members, the organization acheives high organizational commitment (Banner \& Gagne, 1995). Thus, there is a significant positive correlation between two dimensions (Huang,1999).. Furthermore, after comparing management in Hong Kong and Australia, Lok and Crawford (2004) found that the more the management tended to promote an innovative and supportive organizational culture, the more positive was the impact on organizational commitment. In addition, Wann-Yih Wu et al. (2006) studied pharmaceutical factories with different nationalities in Taiwan. They found both supportive and innovative organizational cultures had a significant impact on organizational commitment. The higher the consistency and intensity of organizational culture, therefore, the more employees will internalize the organization's values and objectives and conform their behaviors to the organization's interests. In such case, therefore, employees do not tend to leave, be absent, or have low efficiency (Stevens, Beyer, \& Trice, 1978). High-tech organizations should also offer respectable bonuses or stock dividends to employees, thus rewarding employee contributions. Thus, the impact of innovative and supportive culture this study proposes based upon studies of Wallach (1983) and the consideration of high-tech industry employee characteristics on organization commitment, we arrive at the following hypotheses:

Hypothesis 2: If business organizations have different cultural traits, employees will have different intentions of achieving organizational commitment.

Hypothesis 2-1: The more the cultural status of a business organization is close to an innovative culture, the higher employees' intention to organizational commitment.

Hypothesis 2-2: The more the cultural status of a business organization is close to a supportive culture, the higher employees' intention to organizational commitment.

\subsection{Leadership style and organizational commitment}

According to the field of organizational behavior, the leader is the most influential factor of the organization's operation as the individual and the organization integrate. For example, starting from a garage, HP has now developed into a company with 6,700 employees. This process clearly shows that shaping a great enterprise lies in the deeds of its leader (Malone, 2007). Therefore, problems arise when leaders are connected to the ups and downs of the organization and the welfare of employees' work. Leadership also promotes organizational efficacy. Jaskyte (2004) hypothesized that organizational arrangements, work characteristics, and leadership style will correlate with organizational commitment and work satisfaction. Her findings showed that leadership style is an important predictor of organization commitment and work satisfaction, proving leadership style will affect organizational commitment. A study by Zhou et al. (2005) on 2,754 employees in 180 companies in China showed that leadership style has a positive impact on employees' organizational commitment, work satisfaction, and the future performance of the company. In addition, Walumbwa et al. (2005) focused on the relationship between transformational leadership and organizational commitment of two cultures, namely, the U.S. and Kenya. Their findings showed that transformational leadership had a strong positive impact on organizational commitment in these two cultures. Rajnandini et al. (1999) measured transactional leadership as accidental remuneration behavior and found it has a significant relationship with organizational commitment, again verifying that leadership style affects organizational commitment. Therefore, this study arrives at following hypotheses: 
Hypothesis 3: When the leadership styles of leaders are different, employees will have different intentions in achieving organizational commitment.

Hypothesis 3-1: The more the leader's leadership style is transformational, the higher the employees' intention to organizational commitment.

Hypothesis 3-2: The more the leader's leadership style is transactional, the lower the employees' intention to organizational commitment.

\subsection{Evaluating task performance and its influencing factors}

The so-called "performance" is an evaluation of how well the organizational goals are accomplished and how the company's mission, objective, and purpose have been implemented based on indicators and evaluation means (Duquette \& Stowe, 1993). Performance can be used to reflect the behaviors that an individual adopts to achieve organizational goals and can direct future resource allocations within an organization (Campbell, 1990). Task performance is the quality and quantity of accomplishments an individual or a group performs. It is behavioral, based on events, measurable, and multidimensional. It is the total of discontinuous behavioral events an employee performs within a standard time and a force used to drive an employee to effectively achieve an organization's objectives (Borman \& Motowidlo, 1993).

Scholars such as Browning (1997), Wipper (1994), Simons and Devorin (1979), Bhada (1984), Elizabeth (1996), Mcgrath (1993) and Donna (1996) considered the measurable indicators of task performance including efficiency, effectiveness, and quality. Borman and Motowidlo (1993), however, thought that efficiency and effectiveness related to task performance should be classified into mission performance, while the quality indicator should be more suitably classified into context performance. Robbins (1998) considered the items that task performance evaluates, dividing them into two types: employee achievement and employee behavior (including certain employee characteristics). Among the items, efficiency and effectiveness should be classified into achievement, while the quality indicator should be classified into task behavior. Employees within the high-tech industry face a rapidly changing external environment. In addition to working efficiently, the characteristics of effectiveness and quality, work behaviors such as spontaneity, concentration, and watchfulness as well as complying with codes of conduct should also be considered. Task achievements such as tacit agreements in teamwork with colleagues, accomplishing objectives, mutually affirming task performance, and the willingness to take on extra tasks should also be evaluated. This study therefore summarizes the arguments of scholars including Borman and Motowidlo (1993), Robbins (1998) and divides task performance into two categories: task behavior and task achievement.

\subsection{Organizational commitment and task performance}

Organizational commitment is the degree to which an employee identifies with the organization and organizational goals and hopes to remain a member of the organization (Mayer \& David, 1998). Organizational commitment causes employees to identify with the organization, be proud of being a member, and reflect these in task performance. In other words, the employee behaves as if he identifies with the organization's values and tries his or her best to help the organization achieve its goals. Organizational commitment enables organization members to achieve the expected, stipulated, or formalized demands of their role (Campbell, 1990). The higher an employee's loyalty and sense of identification with an organization and how much he or she participates in organizational activities, the more active he or she will be in those activities and the higher his or her organizational commitment will be (Robbins, 2001). The employee will transform his or her organizational commitment into hard work and will expect to perform for the organization. Thus, an employee with high organizational commitment will show the best task performance, including proactive task behaviors and task achievement by making efforts to reach organizational goals (Steers, 1977). Hence, this study infers the following hypotheses:

Hypothesis 4: The higher the employee's commitment to the business organization, the better the employee's performance of task achievement will be.

Hypothesis 4-1: The more normative the employee's commitment to the business organization, the better the employee's performance of task achievement will be.

Hypothesis 4-2: The more exchangeable the employee's commitment to the business organization, the better the employee's performance of task achievement will be.

\subsection{Personality characteristics, organizational commitment, and task performance}

Every employee has different personality characteristics that will influence employee behavioral models and can be used to forecast the performance of personal behaviors (Wiggins, 1996). If an enterprise knows whether an employee has internal/external control characteristics (whether he or she controls everything him- or herself or whether everything is 
controlled by external conditions) and whether an employee has a type A or B personality (he or she sets deadlines with the goal of achieving more within a short time or the work pace is relatively slow) the enterprise can assign appropriate duties according to the employee's different characteristics. This will enable the employee to accomplish work objectives effectively and work hard to finish tasks as assigned (Brouther, 2002). The enterprise can subsequently recruit qualified talent and retain excellent personnel (Furnham \& Miller, 1997).

Allport (1961) advocated that personality characteristics are the unique style that determines each person's behavior and thinking when adapting to an external environment. Thus, an employee's behavior will reflect his or her unique personality characteristic. After entering an organization, the employee will have loyal emotions to the organization if he or she forms a positive evaluation, offers psychological input, and is able to concentrate on his or her work role (Buchanan, 1974). If an enterprise can use organizational commitment to cause employees to trust and accept organizational goals and motivate employees to work hard, the enterprise will have employees with high organizational commitment. This will help the organization generate positive task performance such as completing tasks within deadlines, achieving a high rate of accomplishing objectives, and reducing customer complaints. Hence, this study infers the following hypotheses:

Hypothesis 5: Different employee personality characteristics will result in different task performance.

Hypothesis 6: When an enterprise has employees with different personality characteristics, employees will have better task performance with the effect of organizational commitment.

\subsection{Organizational culture, organizational commitment, and task performance}

Organizational culture is a model of sharing values and beliefs to develop the company's code of conduct (Osland, Kolb, $\&$ Rubi, 2004). It is also a method to think about and cope with external problems and internal integration issues and can be helpful for organization members to learn about the organization's opinions, ways of dealing with issues and how it takes actions (Griffin, 2005). Therefore, when the organizational culture transforms to guide employee behaviors, this transformation will help promote employee work efficiency.

An enterprise can use organizational culture to bring together all members in the organization and generate organizational commitment such that the employee identifies with the organization and its goals and hopes to become a permanent member of the organization (Mitchell, 1992, Robbins, 2001). As such, employees will be more willing to exert effort in order to gain recognition from directors and the organization (Angle \& Perry, 1981), which will be helpful for achieving task objectives within the employee's role (Brouther, 2002) and help employees promote work efficiency. Hence, this study infers the following hypotheses:

Hypothesis 7: If a business organization has different cultural traits, employees will have different intentions for achieving task performance.

Hypothesis 8: A business organization's different cultural traits will help employees achieve better task performance due to the effect of organizational commitment.

\subsection{Leadership style, organizational commitment, and task performance}

Leadership is the art of achieving a task goal using the talents of others (Mhut, 2002) and increasing organization members' confidence that they can achieve organizational goals (Dubrin, 2001). Leadership, therefore, can be defined as the capacity of affecting a group to achieve goals (Robbins, 2001). Yammarino and Bass (1990) noted that a transformational leader knows how to inspirit followers to make them try their best and achieve high standards of performance. Bass (1985) posited that the transactional leader, in contrast, pays attention to the process such that leaders exchange reward commitment with subordinates. This enables employees to gain rewards and strive for organizational goals.

Leaders can use tangible and intangible conditions to transact with subordinates and thus be transactional leaders. Alternately, they can be transformational leaders who promote followers' hierarchy of needs using personal charm, concerns about followers, and intellectual stimulation. If organizational commitment can be created such that it promotes employees' hopes of remaining a member of the organization, it will help reduce employees' turnover tendencies (Micales \& Spector, 1982), enable them to focus on their tasks, and strive to achieve organizational goals. Hence, this study infers the following hypotheses:

Hypothesis 9: When the leadership styles of leaders are different, employees will have different intentions toward task performance

Hypothesis 10: Different cultural leadership styles of an enterprise will help employees demonstrate better task performance with the effect of organizational commitment. 


\subsection{Establishing a research framework}

Task performance is the basic element through which employees create business value. The purpose of task performance is not only to evaluate the degree to which employees finish their tasks and current working performance, but also allows employees to acknowledge the value, quality and productivity they have created for the organization (Byars \& Rue, 2001). Because the employee's performance is relevant to his or her personality characteristics, an enterprise can enhance its organizational competitive power if it has active, diligent, and spontaneous employees. Likewise, leaders can adopt an open leadership style and organizational culture can bring employees together. Previous research studies on task performance, however, have mostly explored the relationship among value of work, job satisfaction, or organizational commitment without exploring the causality among personality characteristics, organizational culture, leadership style, and organizational commitment. This study thus uses the research framework illustrated in Figure 1, taking personality characteristics, organizational culture, and leadership style as independent variables; organizational commitment as an intervening variable; and task performance as the dependent variable (see Figure 1).

$<$ Figure 1 about here $>$

\section{Research Design}

\subsection{Evaluating the research variable and definition of operability}

Because LISREL possesses the capacity to verify hypotheses, it can also eliminate the obvious multicollinearity of independent variables and one variable being the dependent variable of a certain variable while being the independent variable of another. It is more capable of analyzing the characteristics of complicated causality than general path analysis (Joreskog \& Sorbom, 1993). Moreover, LISREL not only verifies the fitness between global theory model and data style using a chi-square test, but also examines the significance of a specific path by $\mathrm{T}$ value or sequential chi-squire difference test. LISREL is composed of two parts: one is structural equation model, which describes the relationship between latent variables that cannot be observed directly; the other is the evaluation model, which describes the relationship between latent and manifest variables that can be observed directly (Hair et al., 1998). In concert with the research framework, this study preliminarily defined that the latent exogenous variable includes personality characteristics $(\xi 1)$, organizational culture $(\xi 2)$, and leadership style $(\xi 3)$; the latent endogenous variable includes organizational commitment $(\eta 1)$ and task performance $(\eta 2)$. The evaluation will combine the theories and interview experience to develop a 5-point Likert scale questionnaire for a survey. A detailed explanation follows.

\subsubsection{Personality characteristics}

Personality characteristics refer to personal psychological and physiological phenomenon that reveal unique psychological characteristics at different times and under different circumstances. They thus determine the behavioral model and thinking style a person uses to adapt to a particular environment. Personality can be divided into the following two categories:

(1) Internal/external control personality characteristics include the following: job opportunities need to be created by oneself (Rotter, 1954); no matter the task content, it can be accomplished; active actions should be taken if one is not happy with a particular decision; everyone is competent to the task assigned by the organization; everyone can achieve his or her objectives (Brissett \& Newick, 1976;Hsiao, 1999); working hard can make oneself an excellent member of the company (Spector \& O'Connell, 1994); promotion is for those with good task performance (Rotter, 1954); dedication to work deserves remuneration or rewards; and one's actions determine one's own life (Spector \& O' Connell, 1994; Huang \& Lee, 1991; Lai, 1995).

(2) Type A/B personality characteristics include the following: being punctual and never being late for work or meetings; displaying an attitude of active competition (Friedman \& Rosenman, 1974); willing to bear pressure and pursue efficiency (Friedman \& Rosenman, 1974; Caplan \& Jones, 1975; Carrer \& Glass, 1987; Kuo, 1983; Lin, 1987); rarely expressing feelings on issues; volunteering to work overtime or bringing work home; feeling guilty if there is too much free time at work; setting job schedule deadlines; paying attention to personal achievement; not easily angered; and always thinking about unfinished tasks (Jenkins, 1976; Chesney \& Rosenmna, 1980; Hou, 1994).

\subsubsection{Organizational culture}

Organizational culture refers to the value system by which all staff in an enterprise abides; that is, the code of conduct that makes it different from other organizations. Organizational culture can be divided into two categories:

(1) Innovative culture, which has an adventurous and aggressive spirit, encourages employees to accept new concepts that strive for innovation, operates independently, offers autonomy, encourages employees to express opinions and thoughts, collects information relevant to customers (Wallach, 1983). 
(2) Supportive culture, which is characterized by employees cooperating with each other, trust, lacks discrimination, places emphasis on interpersonal relationships, offers encouragement and rewards frequently, and features a harmonized working atmosphere and sense of security (Wallach, 1983).

\subsubsection{Leadership style}

Leadership style exerted by leaders can be divided into two types:

(1) Transformational leadership is characterized by the following: Leaders are respected by employees and act as role models; help employees be proud and pleasant; believe employees have the judgment and capacity to overcome difficulties; use incentives to encourage employees; cause employees to be dedicated to tasks assigned; set high standards for employee task performance (Burns, 1978); are able to envision the direction employees should follow; continually shows concern for one's subordinates; can understand employees' needs; express their appreciation; are willing to offer guidance and encouragement; use new ways of thinking about old problems; and emphasize that employees should use wisdom to solve problems (Lee, 1999).

(2) Transactional leadership is characterized by the following: Desired returns can be gained as long as employees work hard; leaders can bargain with line managers; the degree of input is closely associated with the returns gained; use things for support that employees need to transact; line managers will be satisfied if they use the same methods for continuous good performance (Bass, 1985; Bass \& Avolio, 1989); leaders only talk with employees about the issues about which employees must be aware within the scope of their work; leaders will listen to employees' new practices, but won't actively encourage feedback (Konovsky \& Pugh, 1994).

\subsubsection{Organizational commitment}

Organizational commitment can be divided to two kinds:

(1) Normative commitment is characterized by the following: Organization members have high loyalty to the company and are proud to be a member of the company; they are concerned about the future development and vision of the company; members draw fully on their capacities; the company has great meaning to employees' personal task achievement and career development; members' individual values are very close to company values; the company is an ideal work environment; employees feel satisfied working in the company; members have a deep feeling about the company; employees are willing to offer extra efforts and are responsible for exerting their utmost to their work (Porter et al., 1974).

(2) Exchange commitment is characterized by the following: Organization members do their best to overcome task difficulties; they proactively help colleagues solve problems; they share their work experiences with newcomers; they collect and study information and skills needed for tasks (Stevens, Beyer, \& Trice, 1978); they believe remaining with the company will provide a good future; they hope to work in the company permanently; they exert great mental efforts for the company; they will not consider changing work environments; that is, they are willing to stay with the company and are reluctant to leave (Allen \& Meyer, 1991).

\subsubsection{Task performance}

Task performance is the degree to which an individual inputs effort to an organizational task under the influence of personal knowledge, capacity, and role in the organization. It includes the following: The individual follows standard operating procedures; he or she will find solutions to overcome obstacles; individuals will offer mutual assistance and support to partners when addressing problems at work; an individual will complete tasks per instructions; he or she will promote his or her attention and watchfulness, holding onto a spirit of responsibility and work respect; he or she will pay attention to and comply with issues relevant to security and hygiene at work (Borman \& Motowidlo, 1993). Positive task performance also includes good morale/efficiency/attendance; accomplishing objectives and finishing tasks within schedule; cooperating to achieve organizational goals; affirming partners task performance; having one's work quality affirmed by directors; willing to take extra work; making a great contribution to organization (Robbins, 1998).

\subsection{Sampling subjects and operability model}

In recent years, the high-tech industry has become the center of Taiwan's economic development. High-technology industries can advance Taiwan's economic development effectively because the area is abundant in high-tech talents and cutting-edge techniques and experiences, both of which are important factors for success. Due to the special knowledge and technology required in the operation of high-tech industries, personnel selection must be be given significant attention. Personality characteristics that resist high stress, have a sense of achievement, and are ambitious are necessary to enable a vigorous organization. Such employees allow the organization to achieve remarkable effectiveness and show determination internally and externally. Furthermore, managers in high-tech industries differ significantly from 
leadership in traditional manufacturing and the service industry. Such industry leaders must attend to the speed of production, marketing, and R\&D under severely competitive environments and threats from global competitors. The rate of dismissals and turnover is on the high side, and the trend of job-hopping prevails. Along with the fine specification of work and diversification of talents, recruiting and training talent requires special attention. Therefore employing a leadership style in a environment with special industry characteristics to integrate employees with high knowledge and professional skills; promote their centripetal force and identification with the company; achieve consensus; lead employees to work toward their career mission; and establish work friendships among colleagues with the hope of forming a living community with close relationships among employees and the enterprise can help maintain organizational capacity, even with frequent personnel changes. Previous research studies on the high-tech industry, however, have mainly focused on the strategic application of core capacity and competitive strategy and its advantages. Studies have neglected the significance of evaluating employee personality characteristics and organizational commitment that causes employees to exert efforts for the organization and its goals in order to promote their own task performance. This study therefore takes the high-tech industry as its research object.

This study intends to study the impact of employee personality characteristics, leadership style, and organizational culture on organizational commitment. To be precise and thorough, the study population uses employees from high-tech public companies collected by the Ministry of Finance (Securities Foundation) as subjects. Subjects filled out questionnaires so that recovering the questionnaires was consistent with the study population. A total of 512 questionnaires were distributed with a total of 372 returned. After deducting 68 incomplete responses, the valid questionnaires were 304 , for a valid recovery rate of $59.4 \%$. Operability model established in accordance with research framework is shown in Figure 2.

\section{Data Analysis and Empirical Results}

\subsection{Analysis of validity and reliability}

Validity is a scale that can measure the degree of factors that the researcher want to measure (Chen, 2005), while reliability refers to the consistency of measuring results that a same measurement tool applies on a same research object under various circumstances. First, the questionnaire design of this study refers to relevant literature and the existing circumstances of the high-tech industry. To ensure the completeness and representativeness of the questionnaire content, specialists and practitioners were invited to revise the questionnaire several times. The content validity should meet the standard. At the same time, to verify the construct validity of the questionnaire, correlation coefficients between specific items and overall score is used to delete items of operability definition with no significant relationship. This included action-taking (0.310), easy manifestation (0.245), independent operation (0.383), and standard-setting. In accordance with Kaiser's standard, factor analysis was also used to reserve factors whose eigenvalues are greater than 1 . The same standard is applied to extract the common factor; that is, validity for verification. Second, this study uses Cronbach's $\alpha$ coefficient to evaluate the reliability of the consistency degree of the results received from replicate measurement of the same or similar population. If the reliability coefficient received is beyond 0.80 , it has high level of reliability. In general, if the value is beyond 0.70, it is an acceptable reliability value (Wortzel, 1979). Table 1 shows that Cronbach's $\alpha$ coefficients of this study are between 0.711 and 0.896 , indicating that all evaluation variables meet internal consistency.

$<$ Table 1 about here>

\subsection{Analysis of respondents}

Regarding the basic information of respondents among the 304 valid questionnaires, the proportion of male respondents is $56.2 \%$, while female respondents accounted for $43.8 \%$. In terms of educational status, university (42.1\%) and graduate school or higher $(38.5 \%)$ were found in higher proportions. In terms of years of service, 1-3 years was the highest proportion with $28.9 \%$, followed by $5-10$ years $(21.4 \%)$, and more than 10 years $(18.4 \%)$. Regarding the domestic parent companies' years of establishment, those with a history of more than 20 years had the highest proportion (approximately 46.1\%), while among industry types, employees from communication and information industries had the highest response rate (approximately $28.6 \%$ and $27.3 \%$, respectively). Regarding parent companies' amount of capital, companies with more than NTD5 billion account for $43.1 \%$. Regarding domestic and overseas turnover, those with more than NTD10 billion account for $41.1 \%$. Regarding the number of employees in the parent companies, those with more than 1,001 employees have the highest proportion (approximately 29.3\%), followed by those with 100-250 employees (approximately 28.9\%). It can be seen from the capital amount of the parent companies that the high-tech industry has enormous capital and those with more than 20 years' history and with more than 1001 employees take the highest proportions. 
To confirm whether the variable data in this study complies with the normality assumption for the analysis of structural equation models, normality test with the absolute value of skewness S coefficient less than 3 and the absolute value of kurtosis K factor less than 10 is also used (Kline, 1998). The results are displayed in Table 2. The absolute values of S coefficient of all manifest variables in this study are between $-0.351 \sim 0.602$; the absolute values of $\mathrm{K}$ factor are between $-0.008 \sim 2.199$, all of which meet normality requirements. Furthermore, viewing the average value of all sample companies' evaluation variables, in terms of personality characteristics, type A/B 3.6441 (standard deviation 0.5342 ) is the highest proportion, showing that the personality characteristics of high-tech industry employees are inclined to favor competition, affirmation, are hard-working, have plenty of ambition and are energetic and effective (Friedman \& Rosenman, 1974; Cheseny \& Rosenman, 1980). Third, manifest variables of organizational culture is innovative culture $3.5197(0.7752)$ is higher than supportive culture 3.4485 (0.6991), reflecting that the high-tech industry emphasizes organization members' creativity and challenges, rather than providing and environment with a feeling of family warmth Fourth, in terms of leadership style, transformational leadership $3.4024(0.7466)$ is higher than transactional leadership $3.2146(0.6514)$. In terms of organizational commitment, exchange commitment $3.6102(0.7026)$ appeared as the highest. In terms of task performance, task achievement is higher than task behavior.

$$
<\text { Table } 2 \text { about here }>
$$

\subsection{Fitness testing of overall model}

It is most effecive to have 50-500 samples analyzed using LISREL; otherwise the data be difficult to manage (Hayduk, 1987). The results in fitness of overall model (Table 3) are as follows: (1) the $\chi^{2}$ ratio of the overall sample is 1.678 , complying with the standard of less than 3 ; (2) the fitness indicator GFI is very close to 1 , complying with the testing standard of more than 0.9 ; (3) the adjusted fitness index (AGFI) is more than 0.8 , indicating a fine fitness of the model; (4) the value of the Root Mean Square Residual (RMR) reflecting "fitness residual variance/covariation" is 0.0078 , less than 0.05; (5) Incremental Fit Index (IFI) is larger than 0.9, indicating a perfect fit with the model (Bentler \& Bonett, 1980).

$$
<\text { Table } 3 \text { about here }>
$$

\subsection{Quality test of internal model}

Following the LISREL internal model quality test, this study shows the SMC indicator of the specific manifest variable, which equals the $\mathrm{R}^{2}$ value of the manifest variable and the latent variable are larger than 0.5 (See Table 4). The latent variable element reliability values $(\rho)$ are larger than 0.6, indicating that the Cronbach's $\alpha$ coefficient of observation indicators belonged to every latent variable, has a fairly high reliability. Evaluating construct validity on the basis of the LISREL model covers whether the manifest variable can effectively evaluate the "convergent validity" of one same latent variable and the "discriminant validity" designed for a particular latent variable, whether the manifest variable is different from the manifest variable of other latent variable. In general, convergent validity can be observed through the extraction of average variation of the latent variable. The higher the average variation extraction, the higher the reliability and convergent validity the latent variable will have. Fornell \& Larcker (1981) suggested that only when the normal value is larger than $0.5 \mathrm{can}$ it represent that the average variation explanatory power of the manifest variable on the latent variable is high. The average variation extraction of samples in this study is between $0.7275 \sim 0.9655$ (see Table 4), representing that every manifest variable can receive a considerable degree of latent variable after evaluation (Sharma, 1996).

\section{$<$ Table 4 about here $>$}

Additionally, in terms of discriminant validity (see Table 5), Espinoza (1999) considered the average variation extraction value of a certain latent variable must be larger than the square of the correlation coefficient of a random pair of latent variables on non-diagonal. This is called having discriminant validity capacity. This study has adequate discriminant validity among latent variables.

$$
<\text { Table } 5 \text { about here }>
$$

\subsection{Test of path relationship}

4.5.1 Test of employee personality characteristics, organizational culture, and leadership style against organizational commitment respectively

The high-tech industry selects employees with personality characteristics suitable for the enterprise, who will have better performance on aspects such as value concepts, have effort intention, and job satisfaction. Thus, employees have high organizational commitment to the organization ( $\gamma_{11}$ being 0.30 ) (see Table 6), verifying that hypothesis $\mathrm{H}_{1}$ is supported and echoing the arguments that personality characteristics will affect employees' identification tendency with the 
organization and organizational commitment as emphasized by Hellriegel \& Richards (1998). In addition, the core value style of organization members exists in a strong corporate culture, enough to evaluate employees' identification with and support for organizational culture $\left(\gamma_{21}\right.$ being 0.80 ). This supports hypothesis $\mathrm{H}_{2}$, which is consistent with the arguments that there is a high correlation between organizational culture and organizational commitment proposed by scholars such as Banner and Gagne (1995). This study, however, discovers that leadership style is the key factor affecting organizational operations in former organizations, but because the employees in the current career field are mainly youngsters born in 1980s, they are self-promoting and focus on interactions with colleagues. The use of transactional or transformational leadership style, therefore, is not appealing to them. Therefore, the use of leadership style has no significant effect on organizational commitment ( $\gamma_{31}$ being -0.09$)$. Hypothesis $\mathrm{H}_{3}$ is false by verification.

\subsubsection{Testing of organizational commitment on task performance}

The high-tech industry experiences severe competition. If an enterprise wants to have favorable competitive advantage, the most fundamental element to encourage is employees' investment in their job roles and their positive attitude. Enterprises should help its members develop a sense of identification with the organization as well as the organizational commitment that they are willing to achieve organizational goals. The higher employees' organizational commitment is, the higher their involvement and loyalty to the organization will be. Employees expect the organization to confirm their personal performance and are proud of being a member of the organization; therefore, they will acquire the skills required by tasks and are willing to work with colleagues and complete organizational goals. This cause them to perform well on tasks and gain identification and praise from the directors ( $\beta_{21}$ being 0.46) (Table 6). Hence hypothesis $\mathrm{H}_{4}$ is supported. This also supports the arguments that employees will transform organizational commitment into performing diligent work and expect to create performance for the organization as put forward by scholars including Steers (1977), Mayer and David (1998), Campbell (1990), and Robbins (2001), among others.

4.5.3 Test of employee personality characteristics, organizational culture, and leadership style against task performance, respectively

If a high-tech enterprise finds employees with organization personality traits suitable for the enterprise, employees' task performance will be elevated (Table 6). Moreover, possessing an organizational culture with a common thinking model, criteria for action, and shared values will effectively guide employees to finish tasks correctly and efficiently (Table 6). This verifies that hypotheses $\mathrm{H}_{5}$ and $\mathrm{H}_{7}$ are true.

4.5.4 Testing of employee personality characteristics, organizational culture and leadership style on task performance through organizational commitment

Other than leadership style, personality characteristics and organizational culture have an indirect significant impact on task performance through the intervening variable of organizational commitment. In detail, having employees with different personality characteristics within a high-tech enterprise will have a direct effect on enhancing task performance and will promote employees task performance by making them trust and accept organizational objectives and values. In addition, employees will be willing to internalize organizational objectives and values, making their own behaviors comply with organizational commitment. Hypothesis $\mathrm{H}_{6}$ is thus true by verification. Further, if a high-tech enterprise develops interpersonal relationships, adopts a supportive culture with trust, encouragement, fairness, and openness and encourages an innovative culture that respects organization members' uniqueness and focuses on members' capacity to address challenges and think innovatively, such efforts will have a direct effect on promoting task achievement. If an organizational commitment that enables employees to identify with the organization and objective are combined, this, too, will promote employee task performance. Thus hypothesis $\mathrm{H}_{8}$ is true by verification.

$$
<\text { Table } 6 \text { about here }>
$$

\section{Conclusions and Suggestions}

\subsection{Research conclusion and management implication}

If the high-tech industry wants to create a wellspring of shareholders' fortune with rapidly changing technology, it should be able to choose employees with personality characteristics such as initiative and ambition in addition to having core technologies to reinforce its organizational effectiveness. In addition, an organization must establish a culture focused on trust to motivate employees to devote themselves to the enterprise. Leaders should apply an appropriate leadership style to establish mutual reliance, partnerships, and consensus among organization members in order to reach consensus and make employees feel proud of becoming a member of the organization. This will motivate them to work hard to create persistent competitive advantage for the enterprise. To analyze the difference between the direct impact of personality characteristics, organizational culture, and leadership style on task performance and the indirect impact of organizational commitment on task performance through intervening variables, this study uses LISREL to verify research hypotheses, the conclusions are as follows: 
This study finds that if a high-tech enterprise can select employees with traits such as a preference for competition, affirmation, diligence, ambition, and an energetic and effective work ethic, it will be easy to create an atmosphere of hard work within the enterprise. Employees will be willing to cooperate to achieve organizational goals because they will want to show their talents at work and achieve significant results. These qualities will help promote organizational commitment in terms of sense of belonging, loyalty, and feeling responsible to the organization. This conclusion echoes the argument that personality traits have a significant impact on organizational commitment as proposed by scholars such as Luthans, Baack, and Taylor (1987), Pierce and Dunham (1987). Organizational culture can also regulate employee behaviors internally and provide employees with guidance to adapt to external environments. This is a basic assumption and belief developed by the organization when facing an external environment and internal control. It transfers important hypotheses and norms, governs values, and goals of actions. When entrepreneurs are good at creating an innovative or organizational culture that focuses on employees and gains identification from members within the organization, they will enable members to exert their potential to accomplish the organization's objectives and will increase employees' feeling of be responsible to the organization and organizational commitment (Chien, 2004). Third, scholars such as Steers (1977), Mayer and David (1998), Campbell (1990) and Robbins (2001) proposed that employees will transform organizational commitment into the performance of creating task performance. Thus, high-tech enterprises can increase employees' loyalty, identification, and involvement in the organization by creating organizational commitment such that members believe and accept organizational objectives and values; are willing to make great efforts for the enterprise; and wish to maintain organization membership. As a result, employees task performance will also be enhanced.

The major contribution of this article is that personal characteristics and organizational culture can enhance task performance through organizational commitment. It also tries to investigate whether leadership style and organizational culture will have impact on task performance for employees with different personal characteristics. As the authors did not try to investigate the resulting impact for different sub-industries, future studies may aim at analyzing whether the same results can be observed for different sub-industries and hence provide more detailed information for better managerial decision making.

\subsection{Suggestions for enterprises}

\subsubsection{Identify key talents in organization to help promote competitive advantage of organization}

High-tech enterprises operate in industries with severe competition, and the product life cycles are shorter than other industries. They must rely on new technology, consistent innovation, and R\&D to gain a place in the market. Therefore enterprises should choose employees with personality characteristics such the ability to endure high pressure; possess creativity and provide new constructive ideas and know-how; and actively overcome external obstructions (Brissett \& Nowick, 1976). If the enterprise encounters bottlenecks in development, such employees will be able to think of solutions quickly, which will enable the enterprise to possess a competitive advantage. High-tech enterprises should also learn the 20-70-10 structure proposed by Jack Welch of GE (Welch \& Welch, 2005) to manage talented personnel and sort out employee performance results by using absolute and relative standards. This concept divides employees in the company into the top $20 \%$, the key $70 \%$ and the worst $10 \%$ according to their performances. The company can then offer the best rewards and challenging tasks to the top $20 \%$ by eliminating employees with the worst performance and encouraging the $20 \%$ to lead the organization to excellence. To the key $70 \%$ of employees, more education and training should be provided to enhance their experience and capacity, giving them opportunities to be promoted to the top $20 \%$ (Dick, 2005). Such enterprises can thus maintain their achievements by focusing on evaluating, managing, and cultivating talented personnel.

\subsubsection{To create a knowledge-sharing organizational culture}

Organizational culture is a key factor cohering the centripetal force of organization employees. This study suggests that high-tech industries should not only create a culture encouraging study to promote organization members' continuous learning capacity, but also build a knowledge-sharing culture and values. On the one hand, to strengthen the digital science and technology infrastructure, companies should use standardized system flow, databases, electronic files/e-mails, networking, video/add-on conferencing, and online study to accelerate the diversification of knowledge exchange. On the other hand, high-level executives should provide an interactive organizational learning environment under the shared organizational culture and conventions. They should effectively use formal and informal channels to enable employees to communicate and interact on multiple dimensions and foster mutual trust. This will provoke employees' mutual trust and reciprocity and increase knowledge circulation and sharing. 


\subsubsection{To bring together organization members' centripetal force}

Facing severe competition in the global market environment, enterprises should hire employees who strive to meet organizational objectives and values to cope with the changing environment. 3M or Du Pont, for example, offer financial or non-financial incentives to providers of new commodities, ideas, and proposals (Kanter et al., 1997). In addition to encouraging employees to get involved in tasks and innovation, teamwork can be used to bring together employee involvement and loyalty to the organization and increase employees' normative and exchange commitment. Doing so will help reduce the turnover rate, thus retaining high quality employees with expertise, knowledge, and experience for the enterprise.

\section{References}

Allen, N. J. \& Meyer, J. P. (1991). A Three-Component Conceptualization of Organizational Commitment. Human Resource Management Review. 1(1), 61-89, doi:10.1016/1053-4822(91)90011-Z, http://dx.doi.org/10.1016/1053-4822(91)90011-Z

Allport, G. W. (1961). Pattern and Growth in Personality. New York: Holt, Rinehart \& Winston.

Angle, H. L. \& Perry, J. M. (1981). An Empirican Assessment Organizational Commitment and Organizational Effectiveness. Administrative Science Quarterly. 26(1), 1-14. doi:10.2307/2392596, http://dx.doi.org/10.2307/2392596

Banner, D. K. \& Gagne, T. E. (1995). Designing Effective Organizations: Traditional \& Transformational View. California: Sage Publications.

Bass, B. M. \& Avolio, B. J. (1997). Full Range Leadrship Development. California: Mind Gradern. Inc.

Bass, B. M. (1985). Leadership and Performance beyond Expectations. New York: Free Press

Bass, B. M., \& Avolio, B. J. (1989). Multifactor Leadership Questionnaire-rater Form. Palo Alto, California: Consulting Psychologists Press.

Bentler, P. M. \& Bonett, D. G. (1980). Significance Tests and Goodness Of Fit in The Analysis of Covariance Structures. Psychological Bulletin. 588-606, doi:10.1037/0033-2909.88.3.588, http://dx.doi.org/10.1037/0033-2909.88.3.588

Borman, W. C. \& Motowidlo, S. J. (1993). Expanding the Criterion Domain to Include Elements of Contextual Performance. N. Schmitt, W. C. Borman, \& Associates, Personnel Selection in Organization, San Francisco: Jossey-Bass, 71-98.

Brissett, M. \& Nowicki, S. (1976). Internal vs. External of Reinforcement and Reaction to Frustraction. Journal of Abnormal and Social Psychology. 25, 35-39.

Brouther, K. D. (2002). Institutional, Cultural and Transaction Cost Influences on Entry Mode Choice and Performance. Journal of International Business Studies. 33(2), 203-221. doi:10.1057/palgrave.jibs.8491013, http://dx.doi.org/10.1057/palgrave.jibs.8491013

Browning, E. K. (1997). A Neglected Welfare Cost of Monopoly - and Most Other Product Market Distortions. Journal of Public Economics. 66(1), 127-144, doi:10.1016/S0047-2727(96)01613-1, http://dx.doi.org/10.1016/S0047-2727(96)01613-1

Buchanan, B. (1974). Building Organization Commitment: The Socialization of Managers in Work Organizations. Administrative Science Quarterly. 19(4), 533-546.

Burns, J. M. (1978). Leadership. New York: Harper \& Row.

Byars, L. L. \& Rue, L. W. (2001). Human Resource Management (4th ed.). Burr Ridge: IRWIN.

Campbell, J. P. (1990). Modeling the Performance Prediction Problem in Industrial and Organizational Psychology. Handbook of Industrial and Organizational Psychology. Consulting Psychologists Press, Palo Alto, CA, 1, pp.687-732.

Caplan, R. D. \& Jones, K. W. (1975). Effects of Load, Role Ambiguity and Type a Personality on Anxiety, Depression and Heart Rete. Journal of Applied Psychology. 60(6), 713-719. doi:10.1037/0021-9010.60.6.713, http://dx.doi.org/10.1037/0021-9010.60.6.713

Chen, S. Y. (2005). Multivariate analysis. Taipei: Hwa Tai 
Chien, M. H. (2004). A Study to Improve Organizational Performance: A View from SHRM, Journal of American Academy of Business. 4(1/2), 289-301.

Chien, M. S., Lawler, J. S. \& Uen, J. F. (2010). Performance-Based Pay, Procedural Justice and Job Performance for RD Professionals: Evidence From the Taiwanese High-Tech Sector. International Journal of Human Resource Management. 21(12), 2234-2248, doi:10.1080/09585192.2010.509626, http://dx.doi.org/10.1080/09585192.2010.509626

David V. D. (1989). Personality and Job Performance: Evidence of Incremental Validity. Personnel Psychology. 42(1), 25-36, doi:10.1111/j.1744-6570.1989.tb01549.x, http://dx.doi.org/10.1111/j.1744-6570.1989.tb01549.x

Denison, D. R. (1996). What is the Difference between Organizational Culture and Organizational Climate? A Native's Point of View on a Decade of Paradigm Wars. The Academy of Management Review. 21(3), 619-654, doi:10.5465/AMR.1996.9702100310, http://dx.doi.org/10.5465/AMR.1996.9702100310

Dension, D. R. (1990). Corporate Culture and Organizational Effectiveness. New York: John Wiley \& Sons.

Dobson, J. (1990). The Role of Ethics in Global Corporate Culture. Journal of Business Ethics. 9(6), 481-488. doi:10.1007/BF00382841, http://dx.doi.org/10.1007/BF00382841

Donna, M. S. (1996). Increasing Employee Productivity, Job Satisfaction, and Organizational Commitment. Hospital and Health Services Administration. 41(2), 160-175.

Dubrin, A. J. (2004). Leadership Research Findings, Practice, and Skills (4thEd.). Boston, MA: Houghton Mifflin Company.

Duquette, D. J. \& Stowe, A. M. (1993). A Performance Measurement Model for the Office of Inspector General. Government Accountants. 42(2), 27-50.

Dyer, G. W. (1985). The Cycle of Culture Evolution in Organization. In Ralph Kilmann et. al., Gaining Control of Corporate Culture, San Francison: Jossey-Bass.

Elizabeth, W. M. (1996). Organizational Citizenship Behavior as a Critical Link between HRM Practices and Service Quality. Human Resource Management. 35(4), 493-512.

Espinoza, M. M. (1999). Assessing the Cross-Cultural Applicability of A Service Quality Measure: A Comparative Study Between Quebec and Peru. International Journal of Service Industry Management. 10(5), 449-468. doi:10.1108/09564239910288987, http://dx.doi.org/10.1108/09564239910288987

Fornell, C. \& Larcker, D. (1981). Structural Equation Models With Unobservable Variables and Measurement Errors. Journal of Marketing Research. 18(3), 39-50. doi:10.2307/3151312, http://dx.doi.org/10.2307/3151312

Friedman, M. \& Roseman, R. H. (1974). Type A Behavior and Your Hear. New York: Knopt.

Furnham, A. \& Miller, T. (1997). Personality, Absenteeism and Productivity. Journal of Personality and Individual Differences. 23(4), 705-707, doi:10.1016/S0191-8869(97)00092-5, http://dx.doi.org/10.1016/S0191-8869(97)00092-5

Gardner, M. P. (1985). Creating a Corporate Culture for the Eightier. Business Horizons. 28(1), 59-63, doi:10.1016/0007-6813(85)90040-0, http://dx.doi.org/10.1016/0007-6813(85)90040-0

Gordon, G. G. \& Ditomaso, N. (1992). Predicting Corporate Performance from Organizational Culture. Journal of Management Studies. 29(6), 783-798, doi:10.1111/j.1467-6486.1992.tb00689.x, http://dx.doi.org/10.1111/j.1467-6486.1992.tb00689.x

Greenberg, J., \& Baron, R. A. (2000). Behavior in Organization (7th ed). Engledwood Cliffs. New Jersey: Prentice Hall Inc.

Gustafson, B. M. (2001). Setting the Highest Ethical Leadership Standards Ensures a Higher Standard of Results. Healthcare Financial Management. 55(1), 76-77.

Hagedoorn, J. \& Duysters, G. (2002). The Effect of Mergers And Acquisitions on The Technological Performance of Companies in A High-tech Environment. Technology Analysis \& Strategic Management. 14(1), 67-85. doi:10.1080/09537320220125892, http://dx.doi.org/10.1080/09537320220125892

Hair, J. F. J., Anderson, R. E. Tatham, R. L. \& Black, W. C. (1998). Multivariate Data Analysis (5rd ed). New Jersey: Prentice Hall Inc. 
Hodge, B. J. Anthon, W. P. Y. \& Gales L. M. (1996). Organization Theory: A Strategic Approach (5rd ed.). New Jersey: Prentice-Hall Inc.

Jenkins, C. D. (1976). Recent Evidence Supporting Psychological and Social Risk Factors for Coronary Disease. New England Journal of Medicine. 294, 987-994, 1033-1038. doi:10.1056/NEJM197604292941806, http://dx.doi.org/10.1056/NEJM197604292941806

Joreskog, K. G. \& Sorbom, D. (1993). New Features in LISREL 8. Chicago: Scientific Software Inc.

Kline, R. B. (1998). Principles and Practice of Structural Equation Modeling. New York: Guilford Press.

Koch, J.L. \& R. M. Steers. (1978). Job Attachment, Satisfaction, and Turnover Among Public Sector Employee. Journal of Vocational Behavior. 12(1), 119-128. doi:10.1016/0001-8791(78)90013-1, http://dx.doi.org/10.1016/0001-8791(78)90013-1

Konovsky, M. A. \& Pugh, S. D. (1994). Citizenship Behavior and Social Exchange. Academy of Management Journal. 37(3), 656-669. doi:10.2307/256704, http://dx.doi.org/10.2307/256704

Kuo, T. H., Ho, L.A., Lin, C. \& Lai, K. K. (2010). Employee Empowerment in A Technology Advanced Work Environment. Industrial Management \& Data Systems. 110(1), 24-42, doi:10.1108/02635571011008380, http://dx.doi.org/10.1108/02635571011008380

Luthans, F. Baack, D. \& Taylor, L. (1987). Organizational Commitment: Analysis of Antecedents. Human Relations. 40(4), 219-235, doi:10.1177/001872678704000403, http://dx.doi.org/10.1177/001872678704000403

Mayer, R. C. \& Schoorman, F. D. (1998). Differentiating Antecedents of Organizational Commitment: A Test of March and Simon's Model. Journal of Organizational Behavior. 19(1), 15-28, doi:10.1002/(SICI)1099-1379(199801)19:1<15::AID-JOB816>3.0.CO;2-C, http://dx.doi.org/10.1002/(SICI)1099-1379(199801)19:1\%3C15::AID-JOB816\%3E3.0.CO;2-C

McCalister K. T., Dolbier, C. L., Webster, J. A. Mallon, M. W. \& Steinhardt, M. A. (2006). Hardiness and Support at Work As Predictors of Work Wtress and Job Satisfaction. American Journal of Health Promotion. 20(3),183-191.

Menguc, B. \& Auh, S. (2010). Development and Return on Execution of Product Innovation Capabilities: The Role of Organizational Sturcture. Industrial Marketing Management. 39(5), 820-831, doi:10.1016/j.indmarman.2009.08.004, http://dx.doi.org/10.1016/j.indmarman.2009.08.004

Ministry of Economic Affairs, R.O.C., http://doit.moea.gov.tw(Feb. 10,2011)

Osland, J. S. Kolb, D. A. \& Rubin, I. M. 2004. Organizational Behavior: An Experiential Approach (7rd ed). New Jersey: Pearson Education.

Pervin, L. A. \& John, O. P. (1997). Personality: Theory and research (7rd ed). New York: John Wiley.

Pierce, J. L. \& Dunham, R. B. (1987). Organizational Commitment: Pre-Employment Propensity and Initial Work Experiences. Journal of Management. 13(1), 163-178, doi:10.1177/014920638701300113, http://dx.doi.org/10.1177/014920638701300113

Porter, L. W., Steers, R. M. Mowday, R. T. \& Boulian, P. V. (1974). Organizational Commitment, Job Satisfaction and Turnover among Psychiatric Technicians. Jornal of Applied Psychology. 59(5), 603-609, doi:10.1037/h0037335, http://dx.doi.org/10.1037/h0037335

Reimann, B. C. \& Wiener, Y. (1988). Corporate Culture Avoiding the Elitist Trap. Business Horizons.31(2), 36-44. doi:10.1016/0007-6813(88)90079-1, http://dx.doi.org/10.1016/0007-6813(88)90079-1

Robbins, S. P. (1998). Organizational Behavior (8rd ed). Upper Saddle River, New Jersey: Prentice Hall Inc.

Robbins, S. P. (2001). Organizational Behavior: Concepts, Controversies, and Applications (8rd ed). New York: Prentice Hall Inc.

Rotter, J. (1954). Social Learning and Clinical Psychology. Englewood Cliffs, New Jersey: Prentice-Hall. doi:10.1037/10788-000, http://dx.doi.org/10.1037/10788-000

Schechter, D. S. (1985).Value and Continuance Commitment: A field Test of A Dual Conceptualization of Organizational Commitment. Maryland: College Park.

Schermerhorn J. R. (1989). Experiences in Management and Organizational Behavior. The Academy of Management Review. 1, 138-142.

Sharma, S. (1996). Applied multivariate technique. Hoboken, New Jersey: John Wiley \& Sons. 
Spector, P. E. \& O’Connell, B. J. (1994). The Contribution of Personality Traits, Negative Affective, Locus of Control and Type A to The Subsequent Reports of Job Stressors and Job Strains. Journal of Occupational and Organizational Psychology. 67, 1-11.

Sprenger, R. K. (2004). Trust: The Best Way to Manage. London: Cyan Communications.

Steers, R. M. (1977). Antecedents and Outcomes of Organizational Commitment. Administrative Science Quarterly. 22(1), 46-56. doi:10.2307/2391745, http://dx.doi.org/10.2307/2391745

Stevens, J. M. Beyer, J. M \& Trice, H. M. (1978). Assessing Personal, Role and Organizational Predictors of Managerial Commitment. Academy of Management Journal. 21(3), 380-396. doi:10.2307/255721, http://dx.doi.org/10.2307/255721

Wallach, E. J. (1983). Individuals and Organizations: The Culture Match. Training and Development Journal. 37(2), 29-36.

Wiener, Y. (1982). Commitment in Organizations: A Normative View. The Academy of Management Review. 7(3), 418-428.

Wiggins, J. S. (1996). The Five-Factor Model of Personality: Theoretical Perspectives. New York: Guilford Press.

Williams, L. J., \& Anderson, S. E. (1991). Job Satisfaction and Organizational Commitment as Predictors of Organizational Citizenship and In-Role Behavior. Journal of Management. 17(3), 601- 617, doi:10.1177/014920639101700305, http://dx.doi.org/10.1177/014920639101700305

Wortzel, R. (1979). New Life Style Determinants of Women's Food Shopping Behavior. Journal of Marketing. 43(3), 28-29.

Yammarino, F. J. \& Bass, B. M. (1990). Long-Term Forecasting of Transformational Leadership and Its Effectives Among Naval Officers: Some Preliminary Findings. In Measures of Leadership, ed. K. E. Clark and M. B. Clark. Greensboro, N.C.: Center for Creative Leadership, 151-69.

Yu, M. C., Lin, C. C. \& Hsu, S. Y. (2009). Stressors and Burnout: The Role of Employee Assistance Programs and Self-efficacy. Social Behavior and Personality.37(3),365-377. doi:10.2224/sbp.2009.37.3.365, http://dx.doi.org/10.2224/sbp.2009.37.3.365

Table 1. Reliability Analysis

\begin{tabular}{|c|c|c|c|c|c|}
\hline Latent Variable & Manifest Variables & Cronbach's $\alpha$ & $\begin{array}{l}\text { Latent } \\
\text { Variable }\end{array}$ & $\begin{array}{l}\text { Manifest } \\
\text { Variables }\end{array}$ & Cronbach's $\alpha$ \\
\hline \multirow{2}{*}{$\begin{array}{c}\text { Personality } \\
\text { Characteristics } \\
\xi_{1}\end{array}$} & $\begin{array}{c}\text { Internal / External } \\
\text { Control } X_{1}\end{array}$ & 0.728 & \multirow{2}{*}{$\begin{array}{c}\text { Organizational } \\
\text { Commitment } \\
\eta_{1}\end{array}$} & $\begin{array}{c}\text { Normative } \\
\text { Commitment } Y_{1}\end{array}$ & 0.856 \\
\hline & Type A/B X ${ }_{2}$ & 0.788 & & $\begin{array}{c}\text { Exchange } \\
\text { Commitment } \mathrm{Y}_{2}\end{array}$ & 0.849 \\
\hline \multirow{2}{*}{$\begin{array}{c}\text { Organizational } \\
\text { Culture } \\
\xi_{2}\end{array}$} & \begin{tabular}{|c|} 
Innovative Culture \\
$\mathrm{X}_{3}$ \\
\end{tabular} & 0.840 & \multirow{2}{*}{$\begin{array}{c}\text { Task } \\
\text { Performance } \\
\eta_{2}\end{array}$} & $\begin{array}{c}\text { Work Outcomes } \\
\mathrm{Y}_{3} \\
\end{array}$ & 0.896 \\
\hline & \begin{tabular}{|c|} 
Supportive Culture \\
$\mathrm{X}_{4}$ \\
\end{tabular} & 0.778 & & $\begin{array}{c}\text { Work Behaviour } \\
\mathrm{Y}_{4} \\
\end{array}$ & 0.867 \\
\hline \multirow{2}{*}{$\begin{array}{l}\text { Leadership } \\
\text { Style } \\
\xi_{3}\end{array}$} & $\begin{array}{c}\text { Transformational } \\
\text { Leadership } X_{5} \\
\end{array}$ & 0.845 & & & \\
\hline & $\begin{array}{c}\text { Transactional } \\
\text { Leadership X } \\
\end{array}$ & 0.711 & & & \\
\hline
\end{tabular}


Table 2. Results of Overall Model Fitness

\begin{tabular}{|c|c|c|c|c|c|c|c|}
\hline Manifest Variables & $\begin{array}{c}\text { Coefficient } \\
\text { of Skewed }\end{array}$ & $\begin{array}{c}\text { Coefficient } \\
\text { of Kurtosis }\end{array}$ & Min & Max & Mean & Std. & Var. \\
\hline Internal / External $\mathrm{X}_{1}$ & 0.570 & 0.304 & 1.50 & 5.00 & 3.5822 & 0.6573 & 0.432 \\
\hline Type A/B $\mathrm{X}_{2}$ & 0.111 & 0.197 & 2.00 & 5.00 & 3.6441 & 0.5342 & 0.286 \\
\hline Innovative culture $\mathrm{X}_{3}$ & -0.351 & -0.008 & 1.00 & 5.00 & 3.5197 & 0.7752 & 0.601 \\
\hline Supportive culture $\mathrm{X}_{4}$ & 0.445 & 1.207 & 1.00 & 5.00 & 3.4485 & 0.6991 & 0.489 \\
\hline Transformational leadership $\mathrm{X}_{5}$ & 0.602 & 0.752 & 1.00 & 5.00 & 3.4024 & 0.7466 & 0.557 \\
\hline Transactional leadership $\mathrm{X}_{6}$ & 0.388 & 0.828 & 1.00 & 5.00 & 3.2146 & 0.6514 & 0.424 \\
\hline Normative Commitment $\mathrm{Y}_{1}$ & 0.450 & 0.991 & 1.00 & 5.00 & 3.4353 & 0.6799 & 0.462 \\
\hline Exchange Commitment $\mathrm{Y}_{2}$ & 0.548 & 0.567 & 1.00 & 5.00 & 3.6102 & 0.7026 & 0.494 \\
\hline Work Outcomes $\mathrm{Y}_{3}$ & 0.574 & 2.199 & 1.22 & 5.00 & 3.7387 & 0.5036 & 0.254 \\
\hline Work Behaviour $\mathrm{Y}_{4}$ & 0.377 & 1.817 & 1.00 & 5.00 & 3.5954 & 0.5577 & 0.311 \\
\hline
\end{tabular}

Table 3. Fit Indices for Measurement Model for the Research Model

\begin{tabular}{|c|c|c|c|c|c|c|}
\hline $\begin{array}{c}\text { Fitting Index } \\
\text { and Standard }\end{array}$ & $\chi^{2}$ Ratio $<3$ & RMSEA $<0.08$ & GFI $>0.9$ & AGFI $>0.8$ & RMR $<0.05$ & IFI $>0.9$ \\
\hline Fitting Index & $1.678<3$ & $0.043<0.08$ & $0.97>0.9$ & $0.94>0.8$ & $0.0078<0.05$ & $1.00>0.9$ \\
\hline
\end{tabular}

Table 4. Fitness of Internal Structure of Model

\begin{tabular}{|c|c|c|c|c|c|c|c|c|c|c|}
\hline \multirow[t]{2}{*}{ Item } & \multicolumn{2}{|c|}{$\begin{array}{c}\text { Personality } \\
\text { Characteristics } \\
\left(\xi_{1}\right)\end{array}$} & \multicolumn{2}{|c|}{$\begin{array}{c}\text { Organizational } \\
\text { Culture } \\
\left(\xi_{2}\right)\end{array}$} & \multicolumn{2}{|c|}{$\begin{array}{c}\text { Leadership } \\
\text { Style } \\
\left(\xi_{3}\right)\end{array}$} & \multicolumn{2}{|c|}{$\begin{array}{c}\text { Organizational } \\
\text { Commitment } \\
\left(\eta_{1}\right)\end{array}$} & \multicolumn{2}{|c|}{$\begin{array}{c}\text { Task } \\
\text { Performance } \\
\left(\eta_{2}\right)\end{array}$} \\
\hline & $\mathrm{X}_{1}$ & $\mathrm{X}_{2}$ & $\mathrm{X}_{3}$ & $\mathrm{X}_{4}$ & $\mathrm{X}_{5}$ & $\mathrm{X}_{6}$ & $\mathrm{Y}_{1}$ & $\mathrm{Y}_{2}$ & $\mathrm{Y}_{3}$ & $\mathrm{Y}_{4}$ \\
\hline SMC & 0.43 & 0.94 & 0.59 & 0.78 & 0.89 & 0.98 & 0.62 & 0.52 & 0.78 & 0.81 \\
\hline $\begin{array}{l}\text { Lambda } \\
\text { Loading }\end{array}$ & 0.68 & 0.97 & 0.77 & 0.88 & 0.94 & 0.99 & 0.79 & 0.75 & 0.89 & 0.90 \\
\hline $\mathrm{CR}$ & \multicolumn{2}{|c|}{0.621} & \multicolumn{2}{|c|}{0.804} & \multicolumn{2}{|c|}{0.660} & \multicolumn{2}{|c|}{0.771} & \multicolumn{2}{|c|}{0.885} \\
\hline AVE & \multicolumn{2}{|c|}{0.7275} & \multicolumn{2}{|c|}{0.8370} & \multicolumn{2}{|c|}{0.9655} & \multicolumn{2}{|c|}{0.8135} & \multicolumn{2}{|c|}{0.8985} \\
\hline
\end{tabular}

Table 5. Discriminant Validity

\begin{tabular}{|c|c|c|c|c|c|}
\hline Item & $\begin{array}{c}\text { Personality } \\
\text { Characteristics }\end{array}$ & $\begin{array}{c}\text { Organizational } \\
\text { Culture }\end{array}$ & $\begin{array}{c}\text { Leadership } \\
\text { Style }\end{array}$ & $\begin{array}{c}\text { Organizational } \\
\text { Commitment }\end{array}$ & $\begin{array}{c}\text { Task } \\
\text { Performance }\end{array}$ \\
\hline $\begin{array}{c}\text { Personality } \\
\text { Characteristic }\end{array}$ & 0.7275 & & & & \\
\hline $\begin{array}{c}\text { Organizational } \\
\text { Culture }\end{array}$ & 0.409 & 0.8370 & & & \\
\hline $\begin{array}{c}\text { Leadership } \\
\text { Style }\end{array}$ & 0.411 & 0.657 & 0.9655 & & \\
\hline $\begin{array}{c}\text { Organizational } \\
\text { Commitment }\end{array}$ & 0.398 & 0.682 & 0.525 & 0.8135 & \\
\hline $\begin{array}{c}\text { Task } \\
\text { Performance } \\
\end{array}$ & 0.511 & 0.652 & 0.504 & 0.705 & 0.8985 \\
\hline
\end{tabular}


Table 6. Path Coefficient of Direct and Indirect Effects

\begin{tabular}{|c|c|c|c|c|}
\hline Hypothesis & $\mathrm{H}_{1}\left(\gamma_{11}\right)$ & $\mathrm{H}_{2}\left(\gamma_{21}\right)$ & $\mathrm{H}_{3}\left(\gamma_{31}\right)$ & $\mathrm{H}_{4}\left(\beta_{21}\right)$ \\
\hline Latent Variable & $\begin{array}{c}\text { Personality } \\
\text { Characteristics }\end{array}$ & $\begin{array}{c}\text { Organizational } \\
\text { Culture }\end{array}$ & $\begin{array}{c}\text { Leadership } \\
\text { Style }\end{array}$ & $\begin{array}{c}\text { Organizational } \\
\text { Commitment }\end{array}$ \\
\hline Dependent Variable & $\begin{array}{c}\text { Organizational } \\
\text { Commitment }\end{array}$ & $\begin{array}{c}\text { Organizational } \\
\text { Commitment }\end{array}$ & $\begin{array}{c}\text { Organizational } \\
\text { Commitment }\end{array}$ & $\begin{array}{c}\text { Task } \\
\text { Performance }\end{array}$ \\
\hline Direct Effect & $\begin{array}{c}0.30 * * \\
\mathrm{t}=2.48\end{array}$ & $\begin{array}{l}0.80 * * * \\
\mathrm{t}=7.45 \\
\end{array}$ & $\begin{array}{c}-0.09 \\
\mathrm{t}=-1.33\end{array}$ & $\begin{array}{l}0.46^{* * *} \\
\mathrm{t}=3.46 \\
\end{array}$ \\
\hline Hypothesis & $\mathrm{H}_{5}\left(\gamma_{21}\right)$ & $\mathrm{H}_{7}\left(\gamma_{22}\right)$ & $\mathrm{H}_{9}\left(\gamma_{23}\right)$ & \\
\hline Latent Variable & $\begin{array}{c}\text { Personality } \\
\text { Characteristics }\end{array}$ & $\begin{array}{c}\text { Organizational } \\
\text { Culture }\end{array}$ & $\begin{array}{c}\text { Leadership } \\
\text { Style }\end{array}$ & \\
\hline Dependent Variable & $\begin{array}{c}\text { Task } \\
\text { Performance }\end{array}$ & $\begin{array}{c}\text { Task } \\
\text { Performance } \\
\end{array}$ & $\begin{array}{c}\text { Task } \\
\text { Performance }\end{array}$ & \\
\hline Direct Effect & $\begin{array}{l}0.51 * * * \\
\mathrm{t}=4.93 \\
\end{array}$ & $\begin{array}{l}0.50 * * * \\
\mathrm{t}=6.58 \\
\end{array}$ & $\begin{array}{c}-0.08 \\
\mathrm{t}=-1.55 \\
\end{array}$ & \\
\hline Hypothesis & $\mathrm{H}_{6}$ & $\mathrm{H}_{8}$ & $\mathrm{H}_{10}$ & \\
\hline Latent Variable & $\begin{array}{c}\text { Personality } \\
\text { Characteristics }\end{array}$ & $\begin{array}{c}\text { Organizational } \\
\text { Culture }\end{array}$ & $\begin{array}{l}\text { Leadership } \\
\text { Style }\end{array}$ & \\
\hline Dependent Variable & $\begin{array}{c}\text { Task } \\
\text { Performance }\end{array}$ & $\begin{array}{c}\text { Task } \\
\text { Performance } \\
\end{array}$ & $\begin{array}{c}\text { Task } \\
\text { Performance }\end{array}$ & \\
\hline Indirect Effect & $\begin{array}{c}0.14^{* *} \\
t=2.06\end{array}$ & $\begin{array}{l}0.37 * * * \\
\mathrm{t}=3.20\end{array}$ & $\begin{array}{c}-0.04 \\
t=-1.27\end{array}$ & \\
\hline
\end{tabular}

Annotation: $* \mathrm{p}<0.1, * * \mathrm{p}<0.05, * * * \mathrm{p}<0.01$

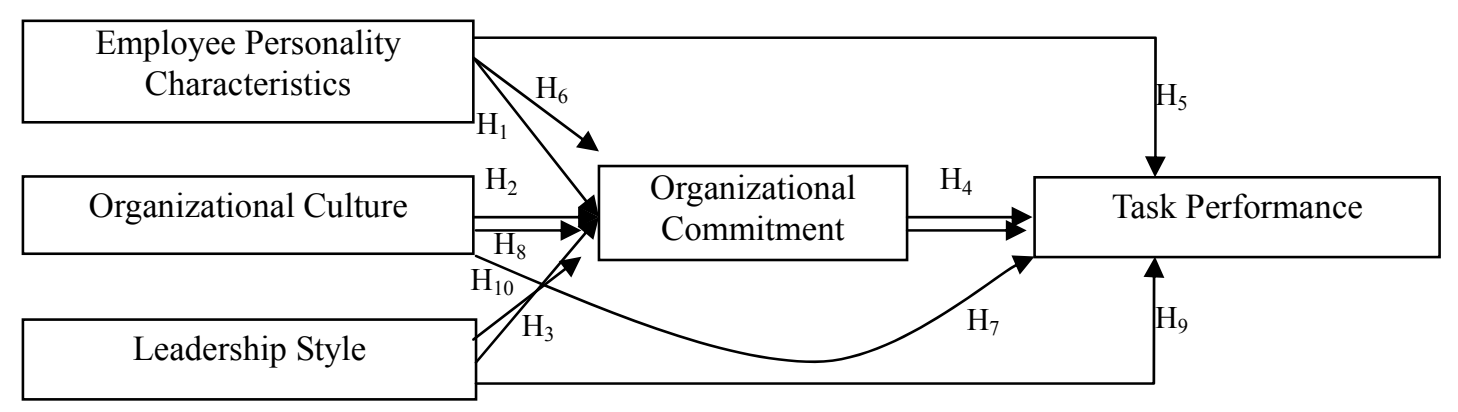

Figure 1. Conceptual Framework

Notes: $\mathrm{H}_{1}, \mathrm{H}_{2}, \mathrm{H}_{3}, \mathrm{H}_{4}, \mathrm{H}_{5}, \mathrm{H}_{7}, \mathrm{H}_{9}$ are Direct Effects; $\mathrm{H}_{6}, \mathrm{H}_{8}, \mathrm{H}_{10}$ are Indirect Effects 


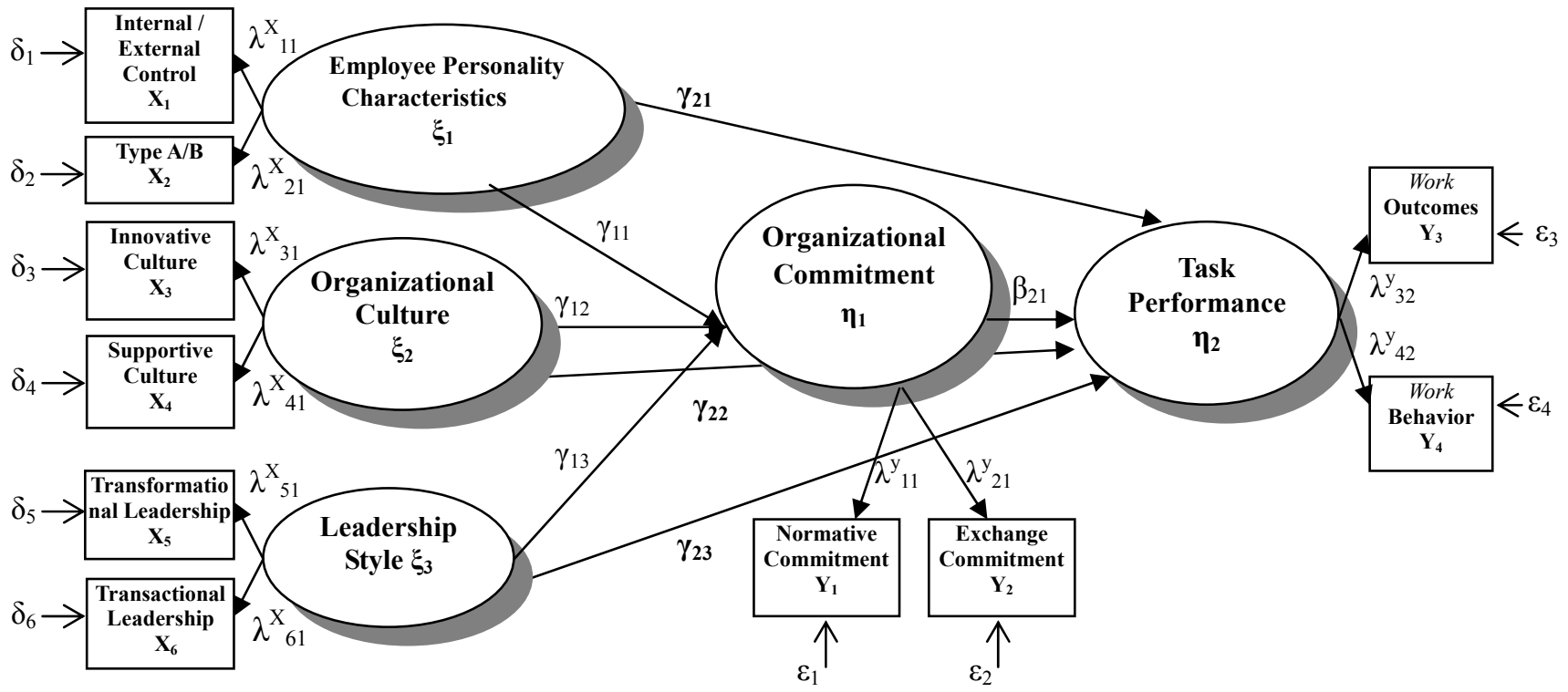

Figure 2. Structure Equation Model of Research 